\title{
METODA AKTIVNOG SINHRONOG UČENJA NA DALJINU
}

\author{
Miroslav Ćajić \\ Osnovna škola „Sveti Sava“, Rogatica, Republika Srpska, BIH
}

\begin{abstract}
:
Osnovna ideja ovog rada bazira se na upotrebi informacionih tehnologija, odnosno, na upotrebi računara i Interneta u obrazovnom sistemu. Sve češća potreba za opravdanim odsustvom sa nastave zbog sportskih, edukativnih ili zdravstvenih problema traži način stalne interakcije između učenika i nastavnika. U ovom radu predstavljen je način upotrebe aktivnog učenja na daljinu uz primjenu sinhrone tehnologije. Osnovni preduslov za implementaciju ove metode učenja je jednistvena literatura koja prati aktuelni NPP. Trenutno, u zemljama okruženja, ovu metodu je moguće primijeniti u vaspitno-obrazovnim ustanovana u Republici Srpskoj. U rada je data komparacija tradicionalnog učenja u odnosu na pomenutu metodu učenja na daljinu.
\end{abstract}

\section{Key words:}

tradicionalno učenje, aktivno i pasivno učenje, sinhrona i asinhrona tehnologija.

\section{UVOD}

Primjena savremenih oblika i metodičke kreativnosti u direktnom vaspitno-obrazovnom radu može biti realizovana upotrebom savremenih izvora znanja koji služe za postizanje optimalnog psihofizičkog razvoja učenika, kao i opšte samostalnosti, naročito u pogledu osposobljavanja učenika za buduće učenje. Upotrebom informaciono-komunikacione tehnologije stvara se mogućnost da uz pomoć računara učenici stiču nova znanja, istražuju, ostvaruju aktivno učešće i dublju interakciju sa nastavnim sadržajem u procesu primjenjivanja savremenih metoda sticanja znanja.

Učenje na daljinu predstavlja metod učenja koji ne zahtijeva fizičku prisutnost učenika na određenom mjestu u toku edukacije. Učenje na daljinu se može definisati kao proces pristupa učenju uz pomoć informacione tehnologije bez fizičke prisutnosti izvoru informacija. [1] Osnova ideje ove vrste učenja podrazumijeva upotrebu računara i Interneta.

Učenje na daljinu, predstavlja novi vid učenja, koji omogućava učenicima savladavanje gradiva uz mogućnost učenja u realnom vremenu. Upotreba Interneta je uslov za interakciju korisnika sa sadržajem, predavačima, odnosno, autorima i ostalim učesnicima u procesu učenja. Ovaj oblik obrazovnog procesa može se razviti zahvaljujući, prije svega, brzom razvoju informacionih tehnologija, računara i računarskih mreža. Metoda aktivnog sinhronog učenja u potpunosti može zamijeniti ranije poznate tradicionalne metode učenja na daljinu. Imajući u vidu već postojanje aktivnog načina učenja koji se u kombinaciji sa sinhronom tehnologijom može kombinovati, dolazimo do jednostavne ideje koju je moguće ostvariti u praksi. Cilj ovog rada je definisanje osnovnih načela aktivnog sinhronog učenja na daljinu koji bi se kroz niz projekata implementirali u djelo.

\section{PRIMJENA}

Sve veći broj učenika značajan dio svojih učeničkih obaveza obavlja kod kuće, koristeći sadržaje s Interneta koji su upravo za njih pripremljeni i oblikovani tako da ih vode kroz proces učenja i savladavanja nastavnog gradiva. Ogroman značaj u ekspanziji ovog oblika obrazovanja ima Internet. Internet je kao globalna računarska mreža u suštini riješio pitanje brzog i relativno jeftinog povezivanja veoma udaljenih subjekata, kao i prevazilaženje tehničkih, jezičkih i drugih barijera u obrazovnom procesu. Primjenom ovakvog sistema učenja, učenici preko web sistema dobijaju dodatne materijale od strane svog mentora ili predavača. Pored toga, predloženi sistem služi predavačima i drugim učenicima za dobijanje dodatnih objašnjenja, razmjenu informacija i rad na zajedničkim zadacima.

Učenje na daljinu, u odnosu na klasični, odnosno, tradicionalni pristup učenju, pokazuje sledeće prednosti [2]:

- stalno učenje (lifelong learning) - učenici uče nezavisno, vlastitim tempom, na mjestu i u vremenu koje sami odaberu,

- brzina učenja - učenici prolaze kroz materijal za učenje onom brzinom i onoliko puta koliko žele,

- mjesto učenja- mjesto se može odabrati i može zavisi od izabrane tehnologije jer učenik pohađa nastavu bez promjene mjesta boravka,

- odabiranje svog načina učenja - aktivno ili pasivno učenje, različiti nivoi interakcije: "klasični" pisani materijal uz vodjenje vlastitih bilješki, interaktivne simulacije, diskusija sa ostalim,

- praktičan rad sa različitim tehnologijama - stiču se ne samo informacije o onome što se uči, nego i dodatna znanja i vještine o korišćenju različitih tehnologija, 
- samostalno učenje - nastavnici uče od učenika koji samostalno traže izvore informacija.

\section{TEHNOLOGIJE}

Sve raspoložive tehnologije koje se mogu koristiti u obrazovanju na daljinu mogu se podijeliti na dvije grupe.

To su [3]:

1. sinhrone i

2. asinhrone tehnologije.

Sinhrone tehnologije podrazumijevaju aktivno učenje. To je način isporuke podataka na mreži u realnom vreme$\mathrm{nu}$, odnosno, gdje su svi učesnici u isto vreme prisutni u toku edukacije. Primjeri sinhrone tehnologije su:

- VoIP

- Telefon

- Video konferencije

- Web konferencije

- Broadcast

- Internet radio

- Live streaming

Asinhrona tehnologija podržava pasivno učenje. To je način na koji učesnici dobijaju materijal za edukaciju po sopstvenom rasporedu, odnosno, učenici ne moraju da budu zajedno u isto vrijeme. Primjeri asinhrone tehnologije su:

- E-mail,

- Forum,

- Štampani materijal,

- Govorna pošta,

- Fax,

- VHS

- CD/DVD,

- On Demand streaming, i sl.

\section{PREDNOSTI}

Poređenjem metoda tradicionalnog učenja i učenja na daljinu može se zaključiti da metoda učenja na daljinu ima prednosti u sledećem: [4]

- Proširenje pristupa: Obrazovanje na daljinu može da se primijeni kod određenog broja učenika koji iz određenih razloga ne mogu da pohađaju školu koja bi im pružila obrazovne usluge koje oni žele.

- Smanjenje troškova: Obrazovanje na daljinu može da smanji troškove obrazovanja kako za učenike tako i za škole. Većina materijala može da bude prosleđena do određenih subjekata bez dodatnih troškova. Učenici prisustvuju predavanjima bez fiksnih troškova vezanih za stanovanje ili smanjenje troškova vezanih za putovanje do mesta održavanja predavanja.

- Izbor škole: Obrazovanje na daljinu omogućava veći izbor obrazovnih ustanova pri odabiru škole. Moguć je odabir škole van mjesta svog prebivališta, bez potrebe za njegovom promjenom, kao i izboru škole van fizičkih granica matične zemlje.
- Prilagođavanje na nove tehnologije i okruženja: Obrazovne institucije mogu da usvoje strateški plan za obrazovanje na daljinu, kao sredstvo da se prilagode brzim promjenama u tehnologiji koja se danas koristi u obrazovanju.

- Proširenje obrazovnih mogućnosti: Obrazovanje na daljinu pruža nove obrazovne mogućnosti za učenike u samoorganizovanju vremena za učenje (visoka motivacija, planiranje vremena i sposobnost za analizu i sintezu sadržaja koji se uči) i dr.

- Fleksibilnost nastave: metoda učenja na daljinu omogućavaju učenicima da prilagode svoje individualne časove. Takođe, pruža im se mogućnosti obavljanja drugih aktivnosti za vrijeme učenja nezavisno od mjesta škole, kao i prevazilaženje nemogućnosti posjete tradicionalnoj redovnoj nastavi usljed nekog od svojih trajnih ili privremenih fizičkih, psihičkih ili socijalnih problema, oštećenja, bolesti ili sportskih razloga.

Tabela 1. Karakteristike nastave i metode učenja

\begin{tabular}{|c|c|c|}
\hline Karakteristike nastave & $\begin{array}{c}\text { Učenje } \\
\text { na } \\
\text { daljinu }\end{array}$ & $\begin{array}{l}\text { Tradi- } \\
\text { cionalno } \\
\text { učenje }\end{array}$ \\
\hline $\begin{array}{l}\text { Nezavisnost od mjesta održavanja } \\
\text { nastave }\end{array}$ & $\mathrm{x}$ & \\
\hline $\begin{array}{l}\text { Nezavisnost od vremena održavanja } \\
\text { nastave }\end{array}$ & $\mathrm{x}$ & \\
\hline $\begin{array}{l}\text { Mogućnost samoorganizovanja vreme- } \\
\text { na za učenje }\end{array}$ & $\mathrm{X}$ & \\
\hline Diskusije sa drugim studentima $24 / 7$ & $\mathrm{X}$ & \\
\hline $\begin{array}{l}\text { Konsultacije sa nastavnikom iz radne } \\
\text { sobe }\end{array}$ & $x$ & \\
\hline Tehnička podrška & $x$ & $x$ \\
\hline Tutorijali & $\mathrm{x}$ & $\mathrm{x}$ \\
\hline Tekstovi za čitanje & $x$ & $\mathrm{X}$ \\
\hline Multimedijalni materijali i nastava & $x$ & \\
\hline Lista dodatnih resursa za učenje & $x$ & $\mathrm{x}$ \\
\hline Neograničeno ponavljanje gradiva & $x$ & \\
\hline $\begin{array}{l}\text { Kvizovi i drugi materijali za provjeru } \\
\text { znanja iz svakog predmeta }\end{array}$ & $x$ & \\
\hline Projekti i seminarski radovi & $x$ & $\mathrm{X}$ \\
\hline Lokacija za učenje na internetu & $x$ & \\
\hline Trenutna dostupnost rezultata & $x$ & \\
\hline $\begin{array}{l}\text { Rječnik pojmova i baza često postavlja- } \\
\text { nih pitanja }\end{array}$ & $x$ & \\
\hline Diploma o završenom školovanju & $\mathrm{x}$ & $\mathrm{x}$ \\
\hline
\end{tabular}




\section{IMPLEMENTACIJA}

Osnovni preduslov za primjenu sinhrone metode učenja na daljinu je jedinstveni Nastavni plan i program koji je predviđen za konkretni proces obrazovanja. Ministarstvo prosvjete i kulture Republike Srpske je donijelo jedinstveni Nastavni plan i program koji se koristi u svim osnovnim i srednjim školama. Drugi preduslov za primjenu ove metode je jedinstvena literatura koja se koristi za konkretan nastavni predmet. Ministarstvo prosvjete i kulture Republike Srpske je donijelo Odluku o upotrebi udžbenika u osnovnim i srednjim školama u Republici Srpskoj čiji je izdavač Zavod za udžbenike i nasatavna sredsta.

Da bi se primijenila metoda aktivnog sinhronog učenja potrebno je ispuniti nekoliko uslova. Ti uslovi se dijele na tehničke i organizacione. U tehnička sredstva spadaju: računar, tablet ili smart telefon, Inrernet komunikacija (kablovski ili WiFi), Aplikacija za prećenje nastave (Skype ili neka druga aplikacija za on-time pregledanje).

Nastavni proces se sastoji od dva ili više učesnika. Nastavnik, kao dominantan subjekat u nastavnom procesu predstavlja izvor informacija. Informacije koje se prezentuju drugoj strani usglašene sa NPP i sa rednim brojem časa koji se izvodi za tematsku oblast u konkretnom nastavnom predmetu. To podrazumijeva da broj časova temetske cjeline i redni broj nastavne teme, odnosno, oblasti mora biti isti. Ova jedinstvenst se postiže jedino usaglašavanjem NPP i prateće literature. Druga strana u nastavnom procesu je učenik. Praćanje nastave od strane učenika upotrebom metode učenja na daljinu može biti organizovano na dva načina:

- On line, nastava se prati u realnom vremenu,

- On demand, nastava se prati u odgođenom vremenu.

Kod on line nastave nastavnik predaje gradivo učenicima a učenik učestvuje u interakciji. U ovom slučaju učenik je aktivan u cijelom toku časa, bez obzira na svoju geografsku dislokaciju. U slučaju odgođene, on demand, nastave učenik nije u mogućnosti aktivno učestvovati u toku časa, te se njegova interakcija svodi isključivo na samozaključivanje. Odgođena nastava se može organizovati preko nekog od kanala društvenih mreža ili preko nosača medija ko što je CD ili DVD, što je u ovom radu već prethodno objašnjeno.

Glavna prednost ove metode aktivnog sinhronog učenja na daljinu je ta što svaka škola može da organizuje ovaj metod nastave samostalno za sebe. Pri organizovanju ovakve nastave potrebno je zadovoljiti već pomenute tehničke i organizacione ulove. Za implementaciju metode $\mathrm{u}$ razrednoj on line nastavi potrebno je angažovati po pet verifikovanih i stručnih učitelja za svaku smjenu. U Republici Srpskoj razredna nastava se izvodi od prvog do petog razreda. U predmetnoj nastavi obezbjeđuje se dovoljan broj verifikovanih i stručnih nastavnika a njihov broj je srazmjeran broju nastavnih predmeta koji su zastupljeni po Godišnjem programu rada škole. Odabir nastavnika koji će vršiti on line nastavu predlažu nastavni aktivi nastavnih predmeta koji se angažuju u nastavnom procesu. Za svaku smjenu potreban je jedan nastavnik po nastavnom predmetu.

\section{ORGANIZACIJA NASTAVE}

$\mathrm{Za}$ on line nastavu, odnosno, za primjenu metode aktivnog sinhronog učenja, potrebno je da škola ima već prethodno pripremljen raspored časova za svaki rezred za koji se izvodi ovaj vid nastave. Učenici koji nisu u mogućnosti pratiti redovnu nastavu pristupaju on line nastavi preko određene aplikacije. Pristup aplikaciji obezbjeđuje se u skladu sa rasporedom, u određeno vrijme, sa određenim korisničkim parametrima. Parametre predstavljaju lično vlasništvo korisnika i određuje ih škola na zahtijev roditelja, ili staratelja učenika. Prilikom generisanja korisničkog imena i lozinke roditelj ili staratelj učenika dužan je potpisati Izjavu o upotebi korisničkih podataka.

Za primjenu ove metode potrebno je prethodno pripremiti kabinete za izvođenje nastave. Svaki kabinet treba da ima pristup Internetu, najmanje jednu kameru i računar ili DVR uređaj preko kog se vrši upload video sadržaja. Interent konekcija mora biti zadovoljavajućeg nivoa, odnosno, da ima najmanje $1024 \mathrm{Kbps}$ brzinu slanja podataka. Nastava se organizuje po časovima. Počinje u već raspoređeno vrijeme i završava se u skladu sa rasporedom časova. Primjenom aktivne sinhrone metode učenja na daljinu omogućava se praćenje nastave za učenike koji nisu u mogućnosti redovno pratiti nastavu iz opravdanih razloga. Ova metoda može da se organizuje i na nivou aktiva škola. U ovom slučaju, npr. za Sarajevsko-romanijsku regiju, nastava bi se izvodila u nekolio izabranih škola a izbor škola bi se vršio na sastanku aktiva direktora. U izabranim školama izvodila bi se nastava samo za određene nastavne predmete. $U$ ovom slučaju potrebno je vodoti računa da se časovi ne poklapaju sa istoimenim predmetima koji se izvode u drugoj školi. Ovaj sistem je moguće proširiti i još više, odnosno, nastavu je moguće organizovati na višem, Republičkom nivou. U tom slučaju organizacioni i tehnički troškovi bili bi znatno smanjeni.

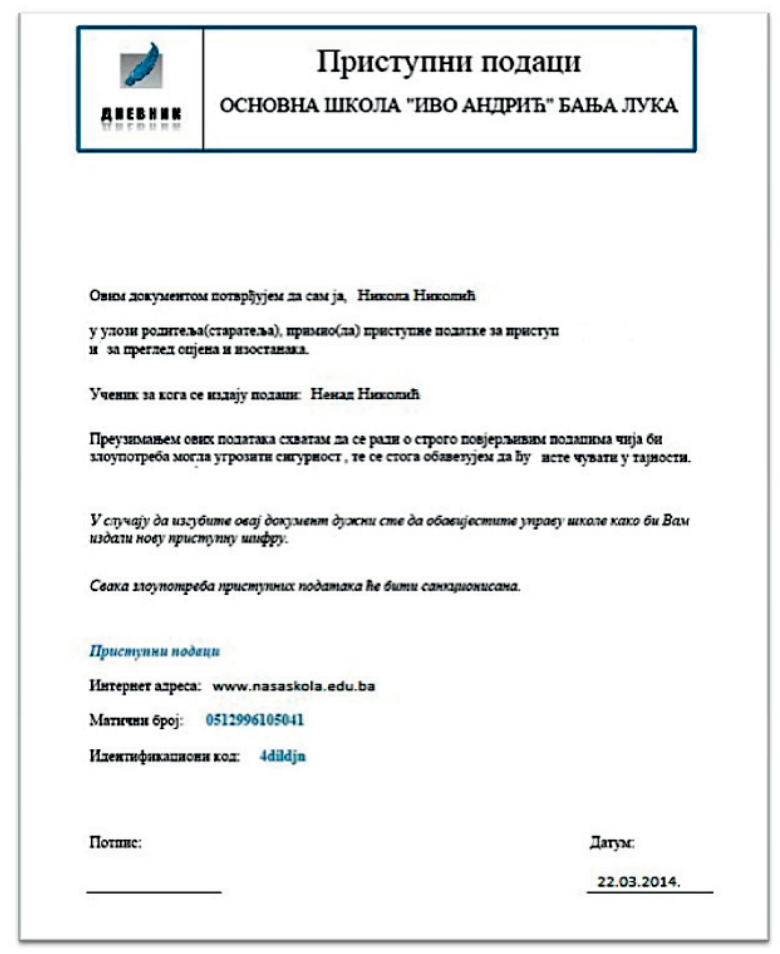

Sl.1. Izjava o upotrebi korisničkih podataka 


\section{ZAKLJUČAK}

Na polju učeničke aktivnosti u velikoj mjeri se izražavaju stavovi u komunikaciji između učenika posredstvom globalne mreže. Primjena metode učenja na daljinu u velikoj mjeri može smanjiti razliku u ekonomskom i socijalnom razvoju mnogih nacija. Internet kao globalna računarska mreža mijenja način učenja i veoma je važno da učenici koji imaju potrebu za učenjem na daljinu imaju pristup informacijama i alatima koji im mogu pomoći pri samom obrazovanju [5]. Učenje na daljinu može poboljšati učenje na više načina. Ono učenicima, njihovim porodicama i nastavnicima donosi iskustvo rada na Internetu i upoznavanje sa njim tokom procesa obrazovanja, pri čemu postaje savršeno virtualno mjesto za učenje. Učenici mogu da uče u svom matičnom gradu, a da se zapravo školuju u nekom drugom mjestu, drugoj školi. Ukoliko učenici imaju pristup kompletnoj bazi materijala za učenje, mogu da razviju veću autonomnost u procesu učenja.[6] Učenici imaju veću kontrolu i mogućnost da upravljaju tokom svog učenja, a uloga nastavnika se pretvara u ulogu mentora ili trenera. Učenje na daljinu mijenja navike i učenika i nastavnika. Uspješni učenici razvijaju upornost i organizacione sposobnosti, a nastavnici postaju vještiji u upotrebi nove tehnologije. Ostvarivanje značajnih rezultatata u vaspitno-obrazovnom radu u okviru procesa nastave ogleda se u osposobljavanju učenika za buduće samostalno upotrebljavanje računarskih tehnologija u domenu lične upotrebe.

Od izabranih softverskih alata koji se mogu koristiti pri učenju na daljina trenutno se najviše koristi Moodle. [7] Pored ovog alata na tržištu se mogu pronaći i drugi, manje poznati, alati. Za predloženu metodu aktivnog sin- hronog učenja moguće je koristiti i ne baš tako sostificiran alat. Dovoljno je na klijentski, odnosno, učenički računar, tablet ili pametni telefon instalirati neku od freeware aplikacija kao što je Skype. Takođe, postoje i softverski alati koji su razvijani individualno od strane određenih pojedinaca ili institucija. Individualizacijom pristupa svakom učeniku uz poštovanje svih pojedinačnih razlika može se postići kreativna i harmonična radna sredina u kojoj se svaki učenik osposobljava za naredno samostalno učenje i obrazovanje uz upotrebu savremenih računarskih pomagala. U budućem radu potrebno je napraviti projekat implementacije metode aktivnog sinhronog učenja na daljinu, bliže odrediti vrstu nastave i utvrditi potrebne Zakonske normative. Kroz niz projekata potrebno je testirati i pilagoditi cjelokupnu programsku platformu konkretnim potrebama obrazovnog sistema. Zbog već naglašenih stavova koji se pominju u radu testiranje bi trebalo obaviti u nekoj od obrazovnih ustanova u Republici Srpskoj.

\section{LITERATURA}

[1] France Bélanger,Dianne H. Jordan, 2000, Evaluation and implementation of distance learning, Idea Group Inc.

[2] Hiroshi, K., Shintaro, I., 2002, Web tools for distance learning, Center for Global Commun., Int. Univ. of Japan, IEEE Conferences.

[3] Gerhardt, L.A., 2005, The future of distance learning, Rensselaer Polytechnic Institute, IEEE Conferences.

[4] http://www.distancelearningnet.com/

[5] http://www.detc.org/otherdownld.html

[6] http://dir.yahoo.com/Education/Distance_Learning

[7] http://www.moodle.org

\section{METHOD OF ACTIVE SYNCHRONOUS DISTANCE LEARNING}

\begin{abstract}
:
The basic idea of this work is based on the use of information technology, respectively, the use of computers and the Internet in the educational system. More frequent need for leave of absence from school because of sports, educational and health problems is seeking a permanent interaction between students and teachers. This paper presents a method of use of active learning with the use of synchronous technology. The main prerequisite for the implementation of this method of learning is of a common literature reveals the current curriculum. Currently in the environment this method can be applied in educational ustanovana the Republic of Serpska. In the work was given to the comparison of traditional learning in relation to this method of distance learning.
\end{abstract}

\section{Key words:}

traditional learning, active and passive learning, synchronous and asynchronous technologies. 